\title{
New identities for district centres
}

Received (in revised form): 2 April 2007

\section{Clifford M. Guy}

is a professor in the School of City and Regional Planning at Cardiff University. His research and teaching interests include retail planning and town centre management. Among his publications are The Retail Development Process (Routledge, 1994) and Planning for Retail Development (Routledge, 2007).

\begin{abstract}
Many district centres in inner urban areas are in decline because their poor shopping environment cannot compete effectively with superstores, retail parks and modernised town centres. Their inexpensive premises, however, allow opportunities for innovative businesses as well as non-profit-making community and arts facilities. This paper examines whether Clifton Street, one of Cardiff's oldest district centres, can be successfully 'branded' as a specialist shopping, service and entertainment destination, while retaining its 'basket shopping' function for local residents and workers. Evidence is derived from surveys of traders and landowners, a planning consultants' study, and interviews with local community interests and potential funders of environmental improvements to the centre. The conclusions are that public sector intervention and finance are essential for the centre's revival, but that there is little case at present for developing a marketing strategy and 'brand' for the centre.
\end{abstract}

\section{Keywords:}

district centres, improvement grants, regeneration, Cardiff

Journal of Retail and Leisure Property (2007) 6, 143-148. doi:10.1057/palgrave.rlp.5100059

Clifford M. Guy

School of City and Regional Planning

Cardiff University

Glamorgan Building King Edward VII Avenue Cardiff $\mathrm{CF}_{10} \mathrm{3}$ WA, UK Tel: +44 (o) 2920875798 Fax: +44 (o) 2920874845 E-mail: guy@cardiff.ac.uk

\section{INTRODUCTION}

District centres in inner urban areas are among the most marginal locations for retail and service businesses. They were originally developed through piecemeal conversion of houses into business premises, serving the everyday needs of the local community. The small size of these premises and a lack of car parking space, however, make it difficult to modernise the retail offer, and many local residents are attracted to more distant but higher quality destinations, including town centres as well as superstores and retail parks. The siting of many district centres on radial routes has, however, attracted uses designed to attract the passing motorist, particularly takeaway foods. These uses sit uneasily 
with the more traditional food retailers, local service providers and a scattering of discount and charity shops.

Little research has taken place recently into the characteristics of and prospects for district centres. A report by the National Retail Planning Forum ${ }^{1}$ suggested that such centres have been less successful in recent years than other areas of secondary shopping, showing higher vacancy rates and greater concern among traders about future prospects.

The regeneration of district centres has become a priority for many local authorities. Current practice emphasises two approaches. First, it is felt that improvements to the physical environment, and pedestrian and vehicle access, will make the centre more attractive to shoppers, and ultimately, property investors. Secondly, in keeping with the increased interest among regeneration circles in place marketing, it is often suggested that the way forward for places in economic decline is to establish a 'role' or 'identity', which can be used in building confidence and in promoting the place concerned to potential investors. It is therefore worth considering whether such an approach should be developed with respect to inner urban district centres.

This paper discusses these two approaches to regenerating district centres, using Clifton Street in Cardiff as a case study.

\section{CLIFTON STREET, CARDIFF: PROBLEMS AND OPPORTUNITIES}

The problems facing Clifton Street, a district shopping and business centre in the inner area of Cardiff, have been discussed previously. ${ }^{2,3}$ The centre is in gradual decline: its traditional function as a shopping destination for the surrounding residential area is weakening as the local population profile changes in character and becomes more mobile. The environment for shoppers is very poor with narrow pavements, heavy traffic, and dilapidated shops and business premises. There have, however, emerged some specialist shops and services which appear to serve a city-wide catchment rather than just local residents. The first of these studies ${ }^{2}$ suggested ways in which both public and private sector interests could act to improve the centre's physical and commercial environment.

In early 2004, surveys of the views of traders and property owners were carried out by Cardiff University, on behalf of the Adamsdown Community Project (ACP). This research showed that ownership of the commercial properties was fragmented among many local business people and small property companies. ${ }^{3}$ In addition, a Cardiff University student carried out research into local residents' use and opinions of Clifton Street ${ }^{4}$ and revealed a strong loyalty to the centre from the local community. All 91 residents surveyed made some use of the centre, although a majority (67 per cent) used it for top-up rather than main shopping. Use for main shopping was most common among the elderly and for households without a car. The most commonly used facilities were newsagent, butcher, baker and post office. Respondents placed high value on Clifton Street as a focal point for the community as well as a convenience shopping destination. 
The present paper serves three purposes. First, it describes recent progress in assessing the centre's problems and potential, including a consultants' study commissioned by Cardiff County Council (CCC), and an analysis of recent changes in the composition of the centre. Secondly, it discusses current proposals for environmental improvements, funded largely by the public sector. This leads to a discussion of Clifton Street's 'identity', and an assessment of the potential for marketing the centre as a destination for local and/or specialist shopping and business services.

\section{THE OFFICIAL RESPONSE}

The initial study of the trading and environmental problems in Clifton Street, ${ }^{2}$ which originated in postgraduate student project work, was used in lobbying CCC in conjunction with the traders association and ACP. Possibly as a result, the Council obtained funding from the Welsh Assembly Government (WAG) for a consultants' study in 2005. The report by Atkins Planning 5 proposed environmental improvements, including one-way traffic, better conditions for pedestrians, a facelift for retail and service premises, and public art works. The report also considered the role of businesses and the public sector in improving commercial viability. It saw the specialist role of the centre growing in importance, and discussed the possible creation of a website to promote specialist retail and businesses.

Following the Atkins report, CCC entered into discussions with local traders and residents, and negotiations with the WAG, with a view to improving environmental conditions within Clifton Street. In 2006, CCC applied to WAG's Physical Regeneration Fund to support the following:

- 'Streetscape improvements', including raised 'table top junctions' to slow the traffic and improve pedestrian access.

- 'Building improvements': facelifts and renovation for commercial premises. This would comprise grants (of between 50 and 80 per cent) offered to property owners by WAG for refurbishment of the building fabric.

Funding for the establishment of craft workshops, in a former church at the northern end of the centre, was also being negotiated under a separate arrangement.

\section{WHERE IS CLIFTON STREET HEADING?}

In order to investigate the current status of Clifton Street and its potential for revival, previous listings of retail and service occupiers in the area were updated. This shows that vacancy rates, which had substantially fallen, have recently increased again (Table 1). The previous improvement had been in line with a general trend across Cardiff as a whole, in which the number of vacant premises in district and local centres fell by 28 per cent between 2001 and $2005 .{ }^{6}$ In Clifton Street, specialist shops (including food) had grown slightly in number until the recent closure of a delicatessen and a fireplace shop. Similarly, the number of restaurants 
Table I: Shop numbers in Clifton Street, 2003-2006

\begin{tabular}{lccc}
\hline & December 2003 & March 2005 & June 2006 \\
\hline Convenience units & 11 & 14 & 11 \\
Comparison units & 31 & 36 & 33 \\
Service units (Pub/ & 18 & 20 & 19 \\
Restaurant/Café/Takeaway) & & & \\
Service units (Other) & 19 & 21 & 21 \\
Vacant units & 25 & 15 & 21 \\
Total units & 103 & 106 & 105 \\
\hline
\end{tabular}

Note: Includes Clifton Street (nos. I-53 and 96-147), Upper Clifton Street, Four Elms Road and Broadway (nos. I-20). Source: Atkins Planning; ${ }^{5}$ Field Surveys

and takeaways has stabilised. At the northern end of the centre, a potential cluster of 'arty' uses has developed, including a gallery, jazz club and bar, and possibly in the future, craft workshops. This cluster (as well as a nearby group of takeaways) benefits from the proximity of the Cardiff School of Art and Design.

The centre as a whole, however, is still congested and shabby for the most part. The many vacant premises include a pub that was closed down by the police in late 2005 . The traders' association has ceased to exist possibly because of the retirement of a leading local figure.

Interviews were carried out in the summer of 2006 with a Community Project fieldworker, and with representatives of CCC and WAG's Department for Enterprise, Innovation and Networks (formerly Welsh Development Agency). These interviews indicated that there is some interest by property investors into refurbishing blocks of properties for retail/service use, with residential on upper floors. It appears that the Atkins study in early 2005 raised interest from property owners and potential occupiers, but this had now waned during negotiations between CCC and WAG. Some premises (including one group of six adjacent units) have been vacant for several years, and it is thought that the owners are waiting for access to grant funding before seeking new occupiers.

Since these interviews have taken place, WAG funding for the streetscape and buildings improvements has been confirmed. For the latter, Town Improvement Grants, for which the freeholder or the person responsible for external maintenance of the building may apply, will be available from Autumn 2007. The process will be managed by CCC, who will tackle each street block in turn, in order to ensure a consistent approach to enhancing the physical appearance of the street. The streetscape improvements will commence in 2008.

Interviewees suggested that the forthcoming traffic improvements and facelift would benefit the centre generally, but in order to retain expenditure among local residents, the convenience shopping offer will need improvement. The availability of grants for refurbishment should encourage investment into improved retail premises, while development of refurbished or new housing in the Street itself and the surrounding area will help support the convenience function. Development of craft workshops would make the northern end of the centre more attractive to specialist retailers and may stimulate the provision of restaurants, 
a facility generally lacking at present. There is little prospect, however, of other parts of Clifton Street taking on a significant specialist function.

One reservation is often expressed concerning the possible effects of environmental and buildings improvements: that rents are likely to increase. This may deter entry by the new specialist businesses that the centre needs to attract, if they can find cheaper premises elsewhere. The convenience shopping sector is also vulnerable to increases in running costs, unless the environmental improvements can be shown to improve sales.

\section{CAN CLIFTON STREET BE MARKETED?}

In south Wales outside Cardiff, local authorities are making efforts to promote their town and district centres to investors, businesses, local people and tourists, through brochures, web pages and special events. Slogans and 'brands' for particular centres are beginning to be used. ${ }^{7}$ Some authorities have also appointed town centre managers to cover several centres within their area. The question arises whether Clifton Street, and other district centres in Cardiff, would benefit from such activity.

Although Clifton Street seems to be maintaining its status in the Cardiff hierarchy of centres, its future direction and potential for some form of marketing or 'branding' are problematic. A brand would only make sense if the centre already possessed a clear identity and purpose. It, however, currently fulfils at least four roles:

- a convenience destination for local needs, especially fresh foods and everyday services

- a source of cheap and second-hand goods, mainly for local needs

- provision of cafés and takeaways, for students and local needs

- specialist retailing and services, but patchy and diversified.

Of these, the first seems to be stable following a long decline. This is a vital function that is highly valued and well supported by local residents. The second is probably in decline and premises tend to be short-lived. The third and fourth are stable in numbers, but some interesting initiatives have proved short-lived. There is little sign of Clifton Street becoming a significant 'niche' destination, even if the craft centre is successful.

In order for the centre to develop a clearer role, there also needs to be some sense of purpose among traders generally, reaching beyond the everyday struggle (in some cases) to make ends meet. The 2004 survey indicates no great enthusiasm for a revival of the traders' association (only 40 per cent of respondents were 'interested' in joining), nor for the setting up of a Clifton Street website (only 19 per cent of respondents, mainly financial services, already had their own website). And, in contrast with some other County Councils in south Wales, there seems little interest within CCC for actively promoting Clifton Street and other such centres.

The conclusion must be that a 'branding' exercise for Clifton Street would be premature at this stage. While the centre clearly needs better 
publicity and marketing, this would require (a) a more positive attitude among traders and landowners, and (b) a clearer role and purpose for the centre itself.

\section{WIDER IMPLICATIONS}

It is not known whether Clifton Street serves as a typical example of an older district centre in a large urban area. It is, however, likely that other such centres face a combination of declining local demand, trader apathy and lack of modern investment. It is also likely that facile attempts at promotion and branding will meet with scepticism among local businesses and residents.

It is vital however that local councils and other public sector bodies show more commitment towards district centres, in order to support local enterprise and employment generation, and to offer good quality shopping to local residents, especially those without cars. It is felt by WAG and CCC that the current programme of improvement outlined in this paper will help to stimulate the refurbishment of premises, leading to growth in demand by potential traders, whether enhancing the convenience function of the centre or developing its specialist strength. To that extent, this case study should be of wider interest.

\section{Acknowledgements}

The author would like to thank Bethan Gamble (Adamsdown Community Project), Hannah Dineen (Cardiff County Council) and Matthew Pizii (Welsh Assembly Government) for their help in providing information for this research. None of these individuals or their employing organisations should be held responsible for any opinions expressed in this paper.

\section{References}

1. National Retail Planning Forum (2004). The Role and Vitality of Secondary Shopping - A New Direction, National Retail Planning Forum, London.

2. Guy, C.M. \& Duckett, M. (2003). Small retailers in an inner city community: A case study of Adamsdown, Cardiff. International Journal of Retail Distribution and Management. 31, 401-407.

3. Guy, C.M. (2005). Revival of inner-city retail areas: The potential role of property owners. Journal of Retail and Leisure Property. 4, 118-128.

4. Rainey, J. (2005). Inner city district centres - Their modern day role and identity in the lives of the local community, Dissertation for MSc Regeneration Studies, Cardiff University.

5. Atkins Planning (2005). Clifton Street Regeneration Strategy: Final Report, Atkins Planning, Cardiff.

6. Cardiff County Council (2006). Retail Floorspace Survey 2005, Cardiff County Council, Cardiff.

7. For example, Caerphilly County Borough Council's 'Bargoed - Big Idea' slogan, online at http://www.caerphilly.gov.uk/visiting/shopping/bargoed/index.htm, accessed 28 March 2007. 